Комчатних О. В., к.е.н. Наиіональний транспортний університет м. Киів, Украӥна

DOI: https://doi.org/10.30525/978-9934-26-080-3-14

\title{
ОСОБЛИВОСТІ ФОРМУВАННЯ ДОДАНОЇ ВАРТОСТІ ТРАНСПОРТНО-ЛОГІСТИЧНИХ ПОСЛУГ
}

В умовах зростання конкуренції на галузевих ринках, динамічного розвитку процесів глобалізації, посилення вимог споживачів до характеристик товарів і послуг сучасний бізнес шукає нові рішення і форми розвитку, що сприяють збереженню ринкової стійкості і формуванню конкурентних переваг, заснованих на створенні доданої вартості. Високий рівень доданої вартості $€$ необхідною умовою досягнення підприємством стійкого й тривалого ділового успіху, а також є одним з головних чинників конкурентоспроможності як на внутрішньому, так і на зовнішньому ринках. 
Величина отриманої підприємством доданої вартості, залежить від багатьох факторів [1]: місця в ланцюгу створення вартості кінцевого продукту; ефективності здійснюваного виду діяльності; виду і призначення продукту, механізму державного регулювання цін на окремі групи продуктів.

Формування доданої вартості транспортно-логістичних послуг відбувається шляхом пропозиції клієнту додаткових логістичних послуг або передбачення та задоволення найбільш затребуваних потреб. Наслідком отримання додаткової вартості є зростання прибутковості і конкурентоспроможності підприємства [2].

Розвиток цифровізації та автоматизації в сфері транспортної логістики поступово призводять до витіснення з ринку представників посередницьких видів діяльності. Вже через 10 років експедиторська діяльність у іï нинішньому вигляді може зникнути 3 логістичного ринку України, і лише робота над створенням суб'єктивної цінності за рахунок впровадження послуг з доданою вартістю дозволить нинішнім експедиторам змінити формат діяльності і втриматись на ринку.

Обслуговуванням 3 доданою вартістю називають унікальні чи особливі дії підприємства для підвищення власної продуктивності та ефективності діяльності, які в свою чергу сприяють укріпленню договірних відносин та зв'язків із споживачами. Щойно підприємство починає приймати індивідуальні рішення, що створюють додану вартість, орієнтуючись на найбільших клієнтів, воно одразу включається в так звану спеціалізовану логістику [3]. Тобто, підприємство починає здійснювати особливі дії для досягнення клієнтом очікуваних результатів. Типові приклади послуг з доданою вартістю легко знайти в ділових стосунках, характерних для стійких i добре налагоджених логістичних каналів.

Для підприємств, що спеціалізуються на перевезеннях вантажів, обслуговування 3 доданою вартістю означає дещо більше ніж базові послуги з транспортування, і включає в себе додаткові послуги, необхідні для задоволення індивідуальних потреб вантажовідправників. До таких послуг слід віднести: 
- сервісні послуги: управління запасами, оренда офісу, гарантійні послуги, ідентифікація, перепакування, маркування, зважування та пломбування вантажів, перевірка кількості і стану вантажу, планування маршрутів, трекінг вантажів, послуги «Якраз вчасно», «Точно в послідовності», зворотня логістика, вантажно-розвантажувальні роботи, розрахунок та формування вантажних місць, надання необхідних пристосувань, складських приміщень або відкритих майданчиків для зберігання, продаж тари та упаковки, надання в оренду рухомого складу, супровід вантажу тощо;

- інформаційні послуги: надання інформації щодо місцезнаходження вантажів та їх переміщення, послуги, тарифи і режими роботи різних експедиторів, наявність вантажу у вантажовідправників, консультаційні послуги в юридичних та адміністративних питань в сфері транспортно-експедиторського обслуговування, розрахунок раціонального завантаження транспортних засобів, передача готових маркетингових та/або IT-рішень тощо;

- фінансові послуги: страхування вантажів, кредитування, логістичний контроль, контроль платежів, виконання розрахунків 3 перевізниками від імені вантажовідправників чи вантажоодержувачів, ведення обліку та звітності для клієнтів, оформлення товарно-транспортної документації, послуги митного оформлення тощо.

Додаткові послуги збільшують привабливість транспортнологістичного підприємства для клієнтів, оскільки надають можливість комплексно вирішувати складні завдання.

Додана вартість транспортно-логістичних послуг формується за чотирма взаємопов' язаними напрямами [4]:

- зниження виробничих витрат за рахунок оптимізації ланцюга постачання;

- зниження витрат на реалізацію за рахунок ефективнішого використання розташування суб'єктів ланцюга постачання;

- скорочення часу виробництва та обігу товарів за рахунок підвищення терміновості, оперативності та своєчасності постачання товарів і послуг; 
- зростання ефективності управління ланцюгами постачання від виробництва до постачання за рахунок більш високої синхронізації циклів і термінів поставок.

Створення послуг 3 доданою вартістю для транспортнологістичних підприємств тісно пов'язано 3 впровадженням інновацій, в т.ч. логістичних. На перший погляд, здійснення перевезень складно віднести до високотехнологічних завдань, проте процеси, які підтримують цей вид діяльності, стають все більш впорядкованими, автоматизованими та інтегрованими. Інновації наповнюють транспортну галузь у вигляді взаємопов'язаних систем постачання, систем відслідковування i трасування вантажів, радіочастотних ідентифікаторів, оптимізації програмного забезпечення тощо.

Українські транспортно-логістичні підприємства функціонують в умовах інтенсивної конкуренції. Через низькі бар'єри для входу на ринок багато невеликих підприємств працює 3 мізерними прибутками, що призводить до обмежених можливостей щодо фінансування інновацій. Так за даними останнього оприлюдненого Держстатом CIS-обстеження [5] упродовж 2016-2018 рр. інноваційною діяльністю займалося 15,5\% транспортних підприємств, в т.ч. логістичні інновації у свою діяльність впроваджували лише $2,6 \%$ серед обстежених транспортних підприємств.

Українські транспортно-логістичні підприємства впроваджували наступні види логістичних інновацій: системи управління запасами (44,6\% транспортних підприємств 3 логістичними інноваціями), цифрове управління ланцюгами постачання (35,1\% транспортних підприємств 3 логістичними інноваціями), електронну комерцію (52,1\% транспортних підприємств 3 логістичними інноваціями), автоматичну ідентифікацію вантажів (11,7\% транспортних підприємств 3 логістичними інноваціями), зворотну логістику (17\% транспортних підприємств 3 логістичними інноваціями), нові моделі доставки (17\% транспортних підприємств 3 логістичними інноваціями), удосконалену доставку (18,1\% транспортних підприємств 3 логістичними інноваціями) та інші 
логістичні інновації $(9,6 \%$ транспортних підприємств 3 логістичними інноваціями).

Стрімкий розвиток технологій та їх постійне старіння призводять до знецінення капіталу та інвестицій в ноу-хау, а логістичний аутсорсинг крім інших переваг може забезпечити вантажовідправникам доступ до нових ресурсів, навичок, досвіду та технологій. Таким чином впровадження логістичних інновацій дозволяє транспортно-логістичним підприємствам збільшити додану вартість послуг, здійснивши перехід від стандартних послуг транспортування та складування до комплексного вирішення логістичних проблем клієнтів.

\section{Література:}

1. Черних О.В., Брюховецька Н.Ю. Особливості формування доданої вартості продукції на промислових підприємствах: Науково-доповідна записка. Київ: Інститут економіки промисловості НАН України, 2018. 34 с. URL: https://agro.dn.gov.ua/naukovo-dopovidna-zapyska-osoblyvosti-formuvannya-dodanoyi-vartosti-produktsiyi-na-promyslovyh-pidpryyemstvah.

2. Гладкий В.Р. Формирование добавленной ценности в транспортнологистических цепях (на примере логистических центров). РИСК: Pecypcb, Информаиия, Снабжение, Конкурениия. 2020. № 1. С. 34-39.

3. Bowersox D.J., Closs D.J., Helferich O.K. Logistical management: The Integrated Supply Chain Process. New York, NY : McGraw-Hill, 1996. 752 p.

4. Мухаметзянова, Л. Х. Формирование добавленной стоимости и критерий дифференциации цепей поставок. Вестник молодых ученых Самарского государственного экономического университета. 2014. № 1(29). С. 207-211.

5. Наукова та інноваційна діяльність в Україні: статистичний збірник. Київ : Державна служба статистики України, 2019. 107 с. URL: http://www.ukrstat.gov.ua. 